\title{
DEVELOPMENT OF CORPORATE SOCIAL RESPONSIBILITY IN BUSINESS AS A FACTOR OF FISCAL DECENTRALIZATION
}

\author{
Valeriia Baranova \\ V.N. Karazin Kharkiv National University, Ukraine \\ Tetiana Kulinich \\ Lviv Polytechnic National University, Ukraine \\ Olena Dutchak \\ Vasyl Stefanyk Precarpathian National University, Ivano-Frankivsk, Ukraine \\ Viktor Zvonar \\ Borys Grinchenko Kyiv University, Ukraine \\ Liudmyla Denyshchenko \\ Volodymyr Dahl East Ukrainian National University, Severodonetsk, Ukraine
}

\begin{abstract}
The purpose of this study was to substantiate the nature of the influence and sustainability of corporate social responsibility (CSR) on the effectiveness of the fiscal decentralization of local government in Ukraine. The estimates of CSR indicators for 490 enterprises were derived from the results of a questionnaire, and the structure of directions for implementing a socially oriented approach in Ukrainian business was determined. Functions of the dependence of indicators of the effectiveness of local authority financial decentralization on CSR development were constructed using linear regression methods and considering the time lag. A stimulating but not sustainable impact of business CSR on increasing the financial base of local budgets in decentralization was identified. The time lag hurts the growth of the company's tax payments due to the growth of the level of CSR. The results obtained from this study can be used to form local government efficiency strategies to initiate CSR development in businesses.
\end{abstract}

Keywords: CSR, business, fiscal decentralization, local authorities, Ukraine

DOI: http://dx.doi.org/10.15549/jeecar.v8i3.760

\section{INTRODUCTION}

The effectiveness of local government in ensuring the sustainability of the socio-economic development of the country's regions should be accompanied by an increase in the resources and financial base of local government and an increase in their autonomy. As best practice 
shows, financially independent local communities with sufficient financial bases can: (1) ensure the implementation of infrastructure and social projects; (2) provide quality services to residents of the region; (3) create attractive conditions for the development of entrepreneurship and attract investment resources; and (4) implement various efficiency programs for the socio-economic development of the region (Kardava, 2018; Scherer \& Palazzo, 2011; Bird, Ebel \& Wallich, 1995).

In Ukraine until 2014, only about 6 of 24 regions were characterized by financial selfsufficiency, which caused a significant regional disparity in the quality of life of Ukrainians (Garus \& Niv'evsky, 2020). These challenges required the implementation of fundamental reforms in public administration, local selfgovernment, and the territorial organization of power in Ukraine. Instead of through federalization, reform financial decentralization was carried out. Financial decentralization was a mechanism for transferring powers from the center to the localities and creating united territorial communities (UTO) which were delegated powers in the distribution of local revenues and fees, as well as determining the conditions of business operations in the region (Reznik \& Slobodianyk, 2021). The effect of fiscal decentralization appeared only in the first two years, however. According to official data, local budgets for 2015-2017 collected from 5\% to 122\% more of local taxes than before the merger and financed $46 \%-569 \%$ more local infrastructure development. In subsequent years, and as of the beginning of 2021, there has been a pronounced tendency towards a significant slowdown in the dynamics of local budgets (Ministry of Finance of Ukraine, 2021). According to leading experts, the current situation is explained by economies of scale, which is confirmed by the tendency to reduce the expenditures of local budgets by $12 \%$ and a decrease by $4 \%$ in labor costs in the regions (Garus \& Niv'evskiy, 2020). The decrease in the costs of local governments in the context of fiscal decentralization can be explained by the destructive impact of the quarantine measures of the COVID-19 pandemic on Ukrainian business. The pandemic worldwide has reduced business activity, and Ukraine is no exception. Steps taken since March last year have complicated an already difficult economic situation, and as a result of the severe restrictions imposed in the economy, many entrepreneurs in the regions found themselves on the brink of survival. Quarantine measures had a particularly detrimental effect on the functioning of Ukrainian small businesses (which is the basis of tax revenues for local communities), as more than $50 \%$ of individual entrepreneurs (IE) became bankrupt (European Business Association, 2020). To support business, the government was forced to reduce taxes burden. This directly affected the level and regularity of revenues to local authorities' budgets, and the local government had to incur additional costs for anti-epidemic measures to combat COVID-19. Consequently, community budgets were characterized by binary losses - lost income and additional expenses.

\section{Problems of Ukrainian business and the need to develop CSR}

Ukrainian business operates in conditions of a decrease in the country's GDP and industrial production. For example, Ukraine's real GDP declined by $4 \%$ in 2020 (State Statistics Service of Ukraine, 2021). According to official statistics, about $33 \%$ of small businesses lost $50 \%-75 \%$ of their income during the introduction of quarantine measures. Most Ukrainian enterprises need 1-3 years to recover their rates of development, and this undoubtedly will reduce the effectiveness of fiscal decentralization (European Business Association, 2020). In crisis conditions, especially concerning the detrimental impact of the humanitarian crisis on business, companies that preserve goals and values aimed at increasing incomes and social responsibility are the winners (Lee, 2020). Business operations in the context of the COVID19 pandemic issues of CSR and professional ethics in the global and Ukrainian business community has come to the fore (Lee, 2020; Reznik \& Slobodianyk, 2021). Few could have imagined that the pandemic would change the attitude of Ukrainian businesses towards CSR, but yet, for most entrepreneurs, CSR is a reliable tool that facilitates the formation of a positive image and strengthens consumer loyalty for large and small and medium-sized businesses (SMEs) (Achyldurdyyeva, Jaw \& Wang, 2019; Reznik \& Slobodianyk, 2021). The support of 
consumers and business partners during a crisis can help a company maintain a business and even increase its profitability.

While the world has been talking about CSR and actively introducing various social strategies into business since the middle of the last century, Ukrainian business has lagged far behind. Only the most progressive and large companies have paid attention to CSR in the last 5-7 years (Pochtovyuk et al., 2019), This, in turn, significantly negates the effect of fiscal decentralization in Ukraine and the financial self-sufficiency of local authorities. The ability of an enterprise to continue productive work and adapt to conditions in emergencies supports not only its own employees in a crisis but also provides all possible assistance to society: these are the signs of efficient business and efficient CSR. In numerous research work by economists, the social responsibility of business is widely discussed in the context of business ethics (Adda, Azigwe \& Awuni, 2016). It, however, is rarely analyzed in connection with new value-semantic aspects of the social activity of business (Pochtovyuk et al., 2019), reflecting complex processes taking place in modern society and as a factor in the fight against the economic and health crises and the effectiveness of reforms in the country. In addition, in Ukraine today the conceptual foundations of implementing CSR principles - ideas about the essence and forms of CSR implementation by business structures - are not properly reflected in the literature (Reznik \& Slobodianyk, 2021). While this problem is especially relevant at the level of regions and municipalities in the context of financial decentralization, the key problem researchers face is the problem of measuring the CSR of a business since CSR is a multilateral process involving many actors and, therefore, difficult to assess. In addition, enterprises differ in their type of activity, industry sector, size, etc., and the choice of approach to measuring CSR is of key importance. Therefore, within the framework of this study, an attempt was made to empirically assess the nature and sustainability of the practical implementation of a socially-oriented approach in Ukrainian businesses on the efficiency of their economic activities and the fiscal decentralization of local governments.

\section{LITERATURE REVIEW}

Research findings generally interpret three general concepts of CSR business structures. The first approach, developed in 1971 by Milton Friedman, was based solely on the commercial interests of entrepreneurs and is called, in theory, "Corporate selfishness" (Mertens, 2013). Corporate selfishness assumed that the only form of responsibility of business structures must be a constant increase in profits and the satisfaction of the commercial interests of stakeholders and shareholders. But increasing competition in the market, tightening labor and environmental standards, increased activity of the trade union movement in the field of requirements for labor protection and social policy, and the progressive culture of consumption proved the ineffectiveness of corporate selfishness and led to the emergence of the opposite concept of CSR development in business - Corporate Altruism (Chen et al., 2020). This direction of the theory of CSR was reflected in an article of the Committee on Economic Development and emphasized that organizations should contribute to the quality of life of the local population and regions (Hohnen, 2007). The main idea is that businesses should take care of the growth of profits and make the most accessible contributions to solving social problems, improving the quality of life of citizens and the community, and preserving the environment (Kendrick, Kendrick \& Saakova, 2014; Achyldurdyyeva, Jaw \& Wang, 2019). The main drawback of this theory, though, is its complete disregard for the fundamental principle of entrepreneurial activity maximizing the profit for the corporation's shareholders, which negates the interest of stakeholders.

The third general CSR concept that best meets the modern needs and conditions of doing business is enlightened self-interest (Young, 2013) which assumes that business spending on various social programs in the long term would bring a return on capital which will ensure the efficiency of the socially oriented business and, most importantly, its sustainability (Peake et al., 2015).

An integrated approach to CSR in business socially anchored competencies - became popular in the 1990s (Osagie et al., 2019). Its 
main advantage lies in the fact that it softens the contradictions between the company's interests and society. There also are many adherents of a unified CSR theory among modern scholars, which is based on a combination of a normative and instrumental approach to substantiating the economic efficiency of a socially oriented business. K. Goodpaster set up the theory of "corporate conscience" in which the corporation is a subject of morality and implying that managers have equal ethical obligations towards all stakeholders (Goodpaster, 2011).

After the approval in 2010 of the International Standard ISO 26000, "Guidelines for Social Responsibility" (ISO 26000: 2010, 2021), experts agreed that CSR facilitates sustainable development and develops concern for the health and well-being of society. A recent study by Walker Information (2021) found a directly proportional relationship between the impact of social activity indicators of business units on a company's business reputation and brand loyalty, which has a greater impact on business sustainability than economic performance. The total profit for the shareholders of companies with high financial and social performance (social performance) has grown by $43 \%$ over the past 15 years. During the same time, this indicator for "simply" financially successful companies grew by only 19\% (Stock market infrastructure development agency of Ukraine, 2021; YouControl, 2021). Many scholars have noted that the positive impact of CSR is largely determined by the specifics of the business structure itself, the peculiarities of its functioning and development. Tiny and unprofitable enterprises or poorly efficient entrepreneurial structures cannot maintain the social orientation of the business.

Based on the foregoing, one can also state that the pressure from and needs of society provoked the development of the institution of CSR and the need for its active implementation in business corporations. (Achyldurdyyeva, Jaw \& Wang, 2019). In Ukraine, at present, there is no pressure as such, and therefore this cannot be a driver for the development of CSR in Ukrainian businesses. At the same time, the government and municipalities for a long time have been exerting constant pressure on business regarding the fact that CSR should become the main channel of communication between business, the state and society in the country. It is difficult to deny that the basic interests of local government, business institutions, and public organizations represent a single system since they are interested in the socio-economic stability and sustainable development of regions. Local government strive to ensure the competitiveness and sustainable development of municipalities based on the use and improvement of the existing potential (Pochtovyuk et al., 2019).

Within the framework of this study, then, the following hypotheses were formulated:

(H1) hypothesis 1: the proposed formulation of CSR and the effect of its impact on business efficiency is generally valid for the success of the business;

(H2) hypothesis 2: active implementation of CSR principles by business structures enhances the positive effect of fiscal decentralization of local budgets;

(H3) hypothesis 3: the effect of fiscal decentralization manifests itself with a time lag as CSR develops in business.

\section{METHODOLOGY}

Indicators to assess the development of CSR in business

The questionnaire method was used to get quantitative assessments of the development of CSR business in Ukraine. The CSR assessment questionnaire was based on a combination of approaches (Newman et al., 2020; Thomson Reuters, 2013), taking into account the concept of stakeholder engagement according to the "quadruple helix" scheme (Malik et al., 2020; Halkiv et al., 2020).

The questionnaire to assess the level of development of CSR organizations in Ukraine was given using the link (Questions for assessing of developing CSR business, 2021) (See Table 1for the list of indicators used). 
Table 1: Indicators for assessing of developing CSR business

\begin{tabular}{|l|c|}
\hline \multicolumn{1}{|c|}{ Indicators } & Symbols \\
\hline Participation in programs to eliminate poverty, hunger, social inequality & CSR1 \\
\hline Financing activities aimed at preventing industrial accidents & CSR2 \\
\hline Harmless to the environment and safe manufactured goods & CSR3 \\
\hline $\begin{array}{l}\text { Compliance with the labor code and international standards that govern working } \\
\text { conditions }\end{array}$ & CSR4 \\
\hline Availability of material and non-material remuneration of personnel & CSR5 \\
\hline Ensuring stable work and staff development opportunities & CSR6 \\
\hline $\begin{array}{l}\text { Absence of manifestations of discrimination (gender, racial, national, social) to } \\
\text { personnel and other interested parties }\end{array}$ & CSR7 \\
\hline $\begin{array}{l}\text { Ensuring the safety of workplaces (including social distancing, provision of personal } \\
\text { protective equipment) }\end{array}$ & CSR8 \\
\hline Provision of teleworking capabilities & CSR9 \\
\hline Improving employee morale & CSR10 \\
\hline $\begin{array}{l}\text { Efficient resource use (energy efficiency, efficient use of water and other natural } \\
\text { resources) }\end{array}$ & CSR11 \\
\hline Use of renewable energy sources & CSR12 \\
\hline Compliance with emissions standards of pollutants into the environment & CSR13 \\
\hline $\begin{array}{l}\text { Implementation of the strategy of ecological waste recycling, the use of ecological } \\
\text { packaging }\end{array}$ & CSR14 \\
\hline Compliance with ethical standards to employees and contractors & CSR15 \\
\hline Transparency of the management system & CSR16 \\
\hline Participation in the development of the infrastructure of the region & CSR17 \\
\hline $\begin{array}{l}\text { Assistance to medical institutions and health workers; financing of the health care } \\
\text { system }\end{array}$ & CSR18 \\
\hline $\begin{array}{l}\text { Assisting in organizing cultural, sports, educational, developmental events in the } \\
\text { region }\end{array}$ & CSR19 \\
\hline $\begin{array}{l}\text { Fulfillment of informal agreements with suppliers and buyers, government, scientific } \\
\text { and other organizations }\end{array}$ & CSR20 \\
\hline $\begin{array}{l}\text { Promoting quality education by providing opportunities for student internships, } \\
\text { training, seminars }\end{array}$ & CSR21 \\
\hline
\end{tabular}

By agreement with the management of the organizations that formed the study sample, questionnaires were sent to the e-mails of their employees who representedlower, middle and upper management levels). The questionnaires carried a score ranging from 0 to 5 points, with a score of 0 meaning disagreement with the approval of the questionnaire and 5 meaning full agreement. The use of a 5-point scale makes it possible to assess the level of CSR and its changes more accurately (Thomson Reuters, 2013). The study involved representatives of SMEs and large companies. The criteria for differentiating enterprises into large and SMEs, was defined by the legislation (On Accounting and Financial Reporting in Ukraine, 1999).

The results of a survey of respondents from 490
Ukrainian organizations were used. Throughout the entire study period, these organizations were not engaged in restructuring, reorganization and/or optimization, which could affect a change in the performance indicators. The organizations were at a stable functioning stage, with the same informational capabilities, to provide a difference in advertising and PR costs which can affect a change in efficiency due to changes in the level of the organization's CSR.

The survey was conducted over a four-year period from April 2017 to April 2021, with the number of respondents from whom feedback was established ranging from 5386 to 5515 people, or 10 to 13 people from each organization. Participation in the survey of more than one representative of each company allows 
checking the level of consistency of opinions regarding the level of CSR in the company, which ensures the reliability of the research results. The results of the survey were anonymous and participation in the survey was voluntary.

In terms of where in Ukraine responses came from, the study was represented by Kiev (96 organizations - $19.59 \%$ of the sample), Kiev region (77 organizations, 15.71\%), Kharkiv (107 organizations, 21.84\%), Lviv (71 organizations, 14.49\%), Dnepropetrovsk (81 organizations, $16.53 \%$ ), and Zaporozhye (58 organizations, $11.84 \%)$. The industries or activities of the studied organizations consisted of the machinebuilding industry (85 organizations, 17.35\%), metallurgy (81 organizations, 16.53\%), light industry ( 83 organizations, $16.94 \%$ ), food (102 organizations $20.82 \%$ ), the chemical industry (29 organizations $5.92 \%$ ), and the service sector (110 organizations, $22.44 \%)$. The study used private enterprises; state-owned enterprises were not used due to additional advantages which arise in connection with the possible participation of the state (as one of the interested parties) in the development of a state-owned enterprise that are not available to private enterprises. Also, enterprises with seasonal production or sales were not used due to quarterly data in the study.

The representativeness of the formed sample was evidenced by its sufficiency - 490 organizations (Taherdoost, 2017).

The complexity of the assessment lies in the fact that there is no generally accepted integral indicator for assessing CSR development. The use of private indicators that correspond to the questionnaire questions without their aggregation does not allow for an unambiguous interpretation of the level of CSR development. Since these indicators have different levels and dynamics, aggregation by highlighting the main components and calculating their values in this study was proposed. The use of the main components made it possible to quantify the development of CSR based on several latent variables. Such variables are also advantageous for modeling because it allows for avoiding multicollinearity without excluding indicators, making it possible to preserve informativeness.

The composition and values of the main components (MC) were calculated using the Statistica 12.0 program. The number of observations corresponds to the answersr eceived from the survey $(\mathrm{N}=26803)$. The variables were the scores on the questionnaire questions ( $l=21$, the number of questions). The adequacy of the results obtained by the method of principal components was confirmed by the number of observations, which is more than $(21+1)$ times the number of variables; the cumulative percentage of variance was 0.93 (Menke, 2018).

\section{Assessment of the impact of the level of CSR development on the efficiency of financial decentralization of local government}

The growth of tax revenues contributes to the growth of the financial stability of the regions and is evidence of the effectiveness of financial decentralization. In this regard, to test hypotheses $\mathrm{H} 1-\mathrm{H} 3$, indicators of CSR development and the growth rate of tax deductions from enterprises (TAX) were used as an indicator of the effectiveness of financial decentralization of local authorities. The TAX indicator is calculated as the basic growth rate of the amount of taxes paid and transferred by the organization to local budgets: 1 sq. the corresponding year - the date before conducting the research.

The complementary influence of CSR development on fiscal decentralization is also manifested in the financing by organizations of measures aimed at regional development. But, as indicators of the results of this study show, the development of this component of CSR is at a low level. It does not significantly affect the financial base of local budgets. Therefore, the role of CSR in the development of fiscal decentralization is assessed only through the dynamics of the tax deductions of organizations.

Regression analysis was used to model the relationship between indicators of CSR development and the dynamics of tax deductions as a factor in the effectiveness of decentralization. The dependent variable was the TAX indicator, and the independent variables were the values of the main components of CSR development. The total number of observations corresponds to the number of organizations studied. As the values of the main components, data on enterprises were used, calculated as the arithmetic mean of the corresponding indicators 
for respondents - representatives of the enterprise. The ability to calculate average indicators is due to the low variability of respondents' assessments within the same enterprise and the consistency of assessments. The coefficient of variation of the respondents' assessments was in the range of $1.3 \%$ to $3.9 \%$.

\section{RESULTS \\ Level and dynamics of CSR development in business}

The surveyed organizations represent different sectors of the economy and regions. The received assessments of the respondents on the questionnaire were checked for statistically significant differences. For this, a t-test for independent samples was used. The empirical values of the criterion are in the range [0.83; 1.18 ] at critical 1.97-1.98, at a significance level of 0.05 . This indicates the absence of statistically significant differences between enterprises depending on their territorial functioning and industry. At the same time, statistically significant differences in the level of CSR development for large enterprises and SMEs were determined at a significance level of 0.05 . The empirical values of the t-test in terms of CSR1-CSR3, CSR6, CSR8-CSR12, CSR14, CSR16CSR19, CSR21 (2.16-3.82) exceed the critical value (1.96). The results of the survey show that the average indicators of CSR development in the sample of SMEs for the period 2017-2021 did not exceed the value of 2.2 , with a potential maximum value of 5 points. The values of indicators of CSR development, CSR1-CSR21, correspond to the point scores of the respondents on the questionnaire.

Most of the indicators are at a low level, as determined by the Fibonacci rule. The low level corresponds to the values of indicators in the range [0;1.9]. Almost all CSR components are at a low level, except for compliance with the rules of the labor code (CSR4), compliance with ethical standards (CSR15), and compliance with stakeholders (CSR20), starting from 2018. An average level of CSR is achieved. For the average level, the range of values of indicators is $(1.9 ; 3.1]$ points.

For large enterprises, the average scores for all indicators are higher and are at the level of 0.92.9, indicating their more developed CSR than SMEs. Mainly for indicators of the inherent average level of development, except for CSR1, CSR3, and CSR12, which are consistently at a low level throughout the study period. These are indicators that characterize the participation of organizations in financing programs to combat poverty and hunger, the production of environmentally friendly products, and the use of renewable energy sources.

The highest values for SMEs are observed for CSR4, CSR15, CSR20, as well as for staff incentive (CSR5), employee morale (CSR10), workplace safety for staff (CSR8), teleworking opportunities (CSR9), and provision of assistance to healthcare facilities and healthcare professionals (CSR18). The values of CSR8, CSR9, and CSR18 indicators increased during the COVID-19 pandemic (20202021) especially. The dynamics of CSR indicators are shown in Figure 1.

CSR1-CSR21, using principal component analysis, were combined into 4 components (MC), which characterize CSR's direction. The number of principal components was determined based on the Kaiser criterion (Menke, 2018). Principal components with eigenvalues exceeding 1.0 are highlighted as significant. The composition of the components is determined based on the values of the factor loadings between the indicators and the main components; economic interpretation of the main components - based on the indicators that formed them. Figure 1 shows the dynamics of the arithmetic mean for the values of the main components. The calculation of average values became possible due to the absence of extreme values for the sample population.

The most significant component is MC1, with a variance of $28.3 \%$. This component reflects the CSR of organizations that are focused on the personal development of employees of all categories and ensuring safe working conditions (prevention of industrial accidents and accidents, compliance with the labor code, provision of personal protective equipment, and the ability to work remotely in the context of the COVID-19 pandemic). 


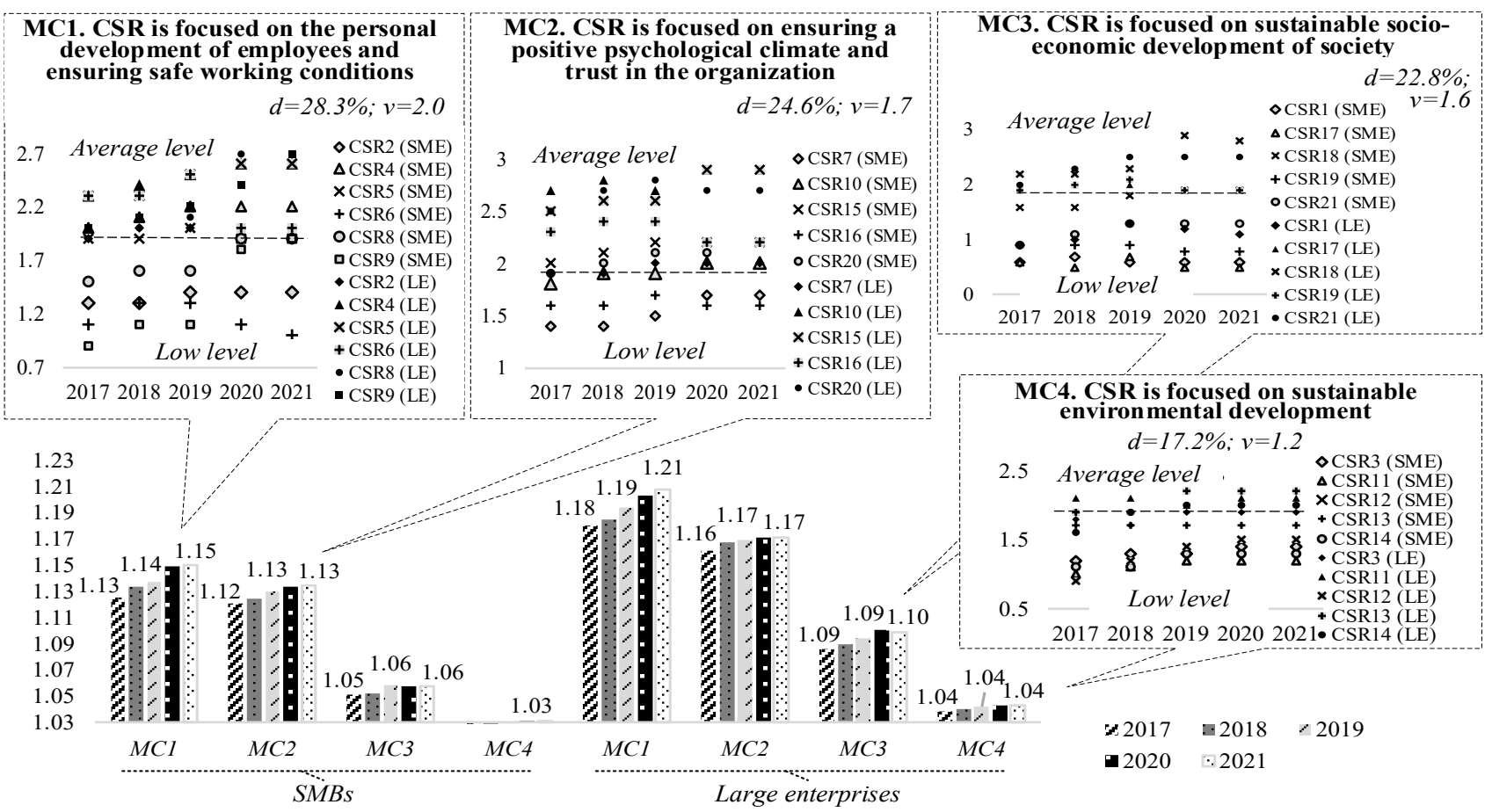

$d$ - variance percentage; $v$ - eigenvalue; $L E$ - values for large enterprises; SME - values for SMEs

Figure 1: Dynamics of CSR indicators of business in Ukraine

Source: Authors' finding

The MC2 component is formed from the indicators CSR7 (which characterizes the absence of manifestations of discrimination in the enterprise), CSR10 (the presence of programs aimed at increasing employee morale), CSR15 (compliance by the enterprise with ethical standards to employees and counterparties), CSR16 (transparency of management), CSR20 (implementation by the enterprise of agreements with stakeholders). This component reflects the focus of CSR on ensuring a positive psychological climate and trust in the organization and is manifested through the absence of manifestations of discrimination and violations of ethical norms, transparency of management, and fulfillment of the organization's responsibilities to employees and stakeholders. The variance of the component is 24.6\%.

The MC3 component explains $22.8 \%$ of the variance and characterizes CSR aimed at sustainable socio-economic development of the region. This development is carried out through participation in programs to eliminate poverty, hunger, social inequality, regional infrastructure development, and assistance in carrying out cultural, sports and educational development events in the region.

MC4 reflects CSR's orientation towards sustainable environmental development: the production of environmentally friendly products, implementation of programs for efficient resource use, use of renewable energy sources, and environmental protection. This factor's variance is $17.2 \%$.

The cumulative percentage of the variance of the MC1-MC4 components is 92.9\%, which indicates a high percentage of factorization, and hence the statistical significance of the results obtained.

Along with the low level of most indicators, the dynamics of the values of the main components also indicate the absence of a trend in the development of CSR; growth in the values of the principal components for 2017-2021 did not exceed $3.2 \%$.

Models to assess the impact of the level of CSR development on the efficiency fiscal 


\section{decentralization of local communities}

For organizations characterized by an increase in the level of CSR, the growth had a positive impact on the dynamics of tax payments. For most of these organizations (66.7\%), the maximum increase in the number of tax deductions was observed with a lag of 1 quarter, $19.8 \%$ without a time lag, and $13.5 \%$ with a lag of 2 quarters. The increase in the number of tax deductions with a lag of 3 quarters does not exceed $1 \%$, and with a lag of 4 quarters $0.5 \%$. In this regard, when constructing regression models of the influence of CSR development on the efficiency of fiscal decentralization, assessed through the indicator of the dynamics of tax deductions, a time lag of 1-4 quarters was used.

Using the Chow test made it possible to determine a structural shift that divides the time range of the study into two: the pre-crisis period (2017-2019) and the period of the pandemic (2020 - Q1 2021). The different nature of the influence of CSR development on the efficiency of financial decentralization of local budgets was determined for these two periods (Table 2).

Table 2: Models of the impact of the level of CSR development on the efficiency of financial decentralization

\begin{tabular}{|c|c|c|c|}
\hline \multirow{2}{*}{$\begin{array}{c}\text { Enterpri e- } \\
\text { class }\end{array}$} & \multirow{2}{*}{ Functional Dependency } & \multicolumn{2}{|c|}{$\begin{array}{l}\text { Critical } \\
\text { values }\end{array}$} \\
\hline & & $\begin{array}{l}\text { F- } \\
\text { test }\end{array}$ & t-test \\
\hline \multicolumn{4}{|c|}{ Pre-crisis period (2017-2019) } \\
\hline $\begin{array}{c}\text { Large } \\
\text { enterprises }\end{array}$ & 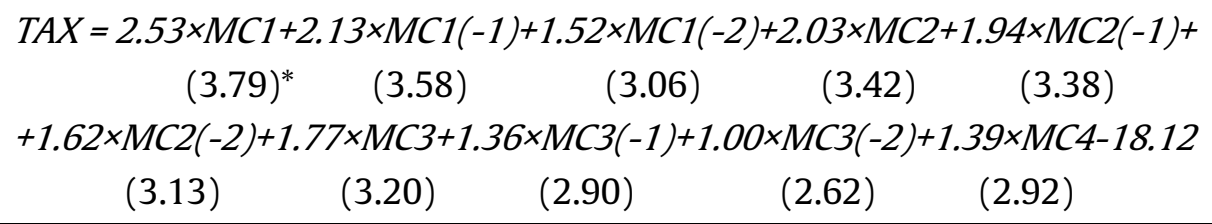 & 1.96 & 1.96 \\
\hline SME & $\begin{array}{l}T A X=2.38 \times M C 1+2.02 \times M C 1(-1)+1.08 \times M C 1(-2)+1.83 \times M C 2+1.45 \times M C 2(-1)+ \\
(3.61) \quad(3.38) \\
+1.03 \times M C 2(-2)+1.50 \times M C 3+1.12 \times M C 3(-1)+1.16 \times M C 4-13.31 \\
(2.11) \\
(2.70)\end{array}$ & 1.95 & 1.96 \\
\hline \multicolumn{4}{|c|}{ COVID-19 Pandemic Period (2020 - Q1 2021) } \\
\hline $\begin{array}{c}\text { Large } \\
\text { enterprises }\end{array}$ & $\begin{array}{l}T A X=3.12 \times M C 1+2.94 \times M C 1(-1)+1.83 \times M C 1(-2)+2.63 \times M C 2+2.28 \times M C 2(-1)+ \\
(5.25) \quad(4.91) \quad(3.38) \\
+2.04 \times M C 2(-2)+2.48 \times M C 3+1.98 \times M C 3(-1)+1.17 \times M C 3(-2)-22.16 \\
(3.50) \quad(3.90) \quad(3.44)\end{array}$ & 2.00 & 1.97 \\
\hline SME & $\begin{array}{l}T A X=2.88 \times M C 1+2.24 \times M C 1(-1)+1.15 \times M C 1(-2)+2.16 \times M C 2+1.86 \times M C 2(-1)+ \\
(3.85) \quad(3.51) \\
+1.10 \times M C 2(-2)+1.92 \times M C 3+1.51 \times M C 3(-1)-14.95 \\
(2.30)\end{array}$ & 1.97 & 1.97 \\
\hline
\end{tabular}

* empirical values of the t-test were indicated in brackets

Source: Authors' finding

For the constructed models, the empirical values Ramsey Test, the Heteroskedasticity Test, and the Normality Test are all greater than 0.05.
The empirical values of the F-criterion are in the range of 22.15-49.42, which exceeds the critical values of 1.95-2.0. This indicates the adequacy of 
the constructed regression models.

All observations testified to the positive impact of companies' CSR growth on the dynamics of their tax payments and, as a result, on the effectiveness of the financial decentralization of local communities. The CSR components are statistically significant, and MC1-MC3 are significant for all models. The empirical values of the t-test for these indicators exceed the critical ones. The MC4 indicator is significant only without lag for the model for 2017-2019.

Comparing the models built based on data from the pre-crisis period and during a pandemic, a more elastic indicator of the growth rate of tax deductions from the dynamics of CSR components during a pandemic was revealed. The calculated average elasticity indicators are shown in Table 3. In the context of the COVID-19 pandemic, an additional burden is created on local budgets due to unprofitable businesses, the bankruptcy of business entities, and an increase in budget expenditures aimed at combating the pandemic. In such conditions, the role of CSR in ensuring the fiscal sustainability of local budgets increased.

Table 3: Elasticity of growth rates of tax deductions from the dynamics of CSR components

\begin{tabular}{|c|c|c|c|c|}
\hline \multirow{2}{*}{ CSR components } & \multicolumn{4}{|c|}{ Elasticity index depending on the components, \% } \\
\cline { 2 - 5 } & \multicolumn{2}{|c|}{ Large enterprises } & \multicolumn{2}{c|}{ SME } \\
\cline { 2 - 5 } & $2017-2019$ & $\begin{array}{c}2020-1 \mathrm{sq} . \\
2021\end{array}$ & $2017-2019$ & $\begin{array}{c}2020-1 \mathrm{sq} . \\
2021 .\end{array}$ \\
\hline MC1 & $4.4 \%$ & $5.6 \%$ & $3.6 \%$ & $4.3 \%$ \\
\hline MC2 & $3.9 \%$ & $4.8 \%$ & $2.9 \%$ & $3.4 \%$ \\
\hline MC3 & $2.7 \%$ & $3.7 \%$ & $1.6 \%$ & $2.1 \%$ \\
\hline MC4 & $0.9 \%$ & - & $0.7 \%$ & - \\
\hline
\end{tabular}

Source: Authors' finding

\section{DISCUSSION AND CONCLUSION}

According to the results of the study, it was found that the development of CSR has a direct positive impact on the profitability of a business, which is manifested in an increase in tax payments to local budgets. Despite the positive impact, there is a significant difference in the degree of influence of CSR components on the resulting indicator of business in Ukraine. The most significant influence on the growth of tax deductions of organizations is exerted by the personal factor of employees, the psychological climate, and working conditions in the organization. This can be explained by the fact that the concept of CSR has not yet found proper reflection in Ukrainian business and is at the initial stage of its implementation and development.

But since the country's standard of living and education is constantly increasing, the possibility of retraining and raising the level of qualifications becomes more accessible. Ukrainians are becoming more aware of how their work and personal life mix and want to work for a company that cares about them as individuals. Therefore, companies need to really take into account the needs of their employees. Being a good employer is about more than just providing wages and traditional benefits, it also means fostering employee contributions to social and environmental issues. This, in turn, subsequently forms a solid framework of motivated and loyal employees in the development of their company, which directly positively affects its profitability and costs. And as a result, it increases the efficiency of the financial decentralization of local authorities in Ukraine. As a socially-oriented approach is adopted in Ukrainian business, companies will also be focused on obtaining the external effects from CSR, such as loyalty and trust of consumers, the formation of strong social and commercial ties with business partners and other 
stakeholders. The expansion of the positive effects from CSR can be observed for larger companies (Achyldurdyyeva, Jaw \& Wang, 2019; Kendrick, Kendrick \& Saakova, 2014). The higher level of CSR development for large enterprises, in comparison with SMEs, has been confirmed statistically, and the higher elasticity of changes in tax deductions with changes in CSR components confirms hypothesis H1. For large enterprises, the effect of CSR development on business efficiency is more significant. At the same time, the efficiency of the business was assessed through the indicator of the dynamics of tax deductions, the amount of which depends on the income and profits of companies, the number of employees, and the level of their remuneration (Odintsov et al., 2020).

It can be argued that the priority of such components of CSR as ensuring safe working conditions, a positive psychological climate, trust, assistance to medical institutions and medical workers, and the financing of health care costs. Against this background, the importance of ensuring sustainable environmental development fades into the background. This explains the statistically insignificant effect of the MC4 component on the dynamics of tax payments during the pandemic. The positive values of the elasticity indicators and the statistically significant influence of the CSR components on the dynamics of tax deductions, confirmed by the constructed regression models, make it possible to accept the $\mathrm{H} 2$ hypothesis. On the other hand, in Ukrainian practice, it is impossible to say with complete confidence that the revealed positive relationship between the level of CSR development, business efficiency, and fiscal decentralization is quite stable. The stability of communication occurs in the case of business in developed countries where a mechanism for assessing the public activities of companies through various public organizations has been established and where corruption is at a relatively low level. There is a transparent system of decision-making by state bodies. There also is a clear connection between responsible behavior and the activities of two other participants: the state and civil society, i.e., where a system of regulation of social relations has been developed, and social relations have a civilized character. In the case of Ukraine, the unstable connection is evidenced by the confirmation of hypothesis $\mathrm{H} 3$; the revealed regularity, according to which, with an increase in the time lag, elasticity decreases. This allows us to conclude that the time lag hurts the growth of company tax payments and the effectiveness of the financial decentralization of local authorities due to the growth of CSR level.

Within the framework of increasing the efficiency of fiscal decentralization, local authorities and communities should actively stimulate the development of the CSR institution in Ukrainian business. Since the solution of the social problems of the local community in which the company operates also makes it possible to replace budget funds with corporate funds. This is undoubtedly positive in conditions of a limited budget (especially in the regions), and social tension can decrease. Providing favorable CSR conditions for employment will again stabilize the situation. These are just some of the benefits CSR brings to local governments. Therefore, local councils should recognize the importance of CSR and convince businesses of this, demonstrate their views, and publicly express their positive attitude towards companies that implement the concept of CSR. Universal support for business and civil society participation in key initiatives through various forms, including partnerships, joint business, a CSR resource center, financial investments in projects, a national network of top managers, and coalitions for social inclusion, etc. should be provided. Thus, the need for state policy in the field of CSR is obvious. A formal approach in the form of creating a certain bureaucratic structure is inappropriate here, however. It is important to remember that the institution of CSR is informal and can function effectively only in a voluntary environment.

The obtained results of this research were based on a sample of exclusively Ukrainian enterprises of large and small businesses. Because CSR development is at the initial stage of its development in Ukraine and has an unstable impact on the efficiency of financial decentralization and business efficiency, the revealed patterns cannot be extended to other countries. 


\section{REFERENCES}

About the introduction of amendments to certain legislative acts of Ukraine, directing to protecting additional social and economic guarantees in connection with the extended coronavirus ailments (COVID-19) (2020). Law of Ukraine on March 30, 2020 № 540IX.

https://zakon.rada.gov.ua/laws/show/en/54 0-20\#Text

Achyldurdyyeva, J., Jaw, B.-S., \& Wang, C. Y.-P. (2019). Foreign companies' CSR themes and objectives in Central Asia. Journal of Eastern European and Central Asian Research, 6(2), 331-343.

https://doi.org/10.15549/jeecar.v6i2.279

Adda, G., Azigwe, J.B., \& Awuni, A.R. (2016). Business Ethics and Corporate Social Responsibility for Business Success and Growth. European Journal of Business and Innovation Research, 4, 6, 26-42.

Bird, R.M., Ebel, R.D., \& Wallich, C. (1995). Decentralization of the Socialist State: Intergovernmental Finance in Transition Economies. The International Bank for Reconstruction and Development. Washington.

Chen, J., Dong, W., Tong, Y., \& Zhang, F. (2020). Corporate philanthropy and corporate misconduct: Evidence from China. International Review of Economics \& Finance, 65, 17-31. https://doi.org/10.1016/j.iref.2019.09.002

European Business Association. (2020). Onethird of small businesses lost more than 50\% of their income. https://eba.com.ua/en/tretyna-malyhpidpryyemtsiv-vtratyly-bilshe-50-dohodiv/

Garus, A., \& Niv'evskiy, O. (2020). One has strength. Influencing the reform of decentralization on the local budgets in Ukraine.https://voxukraine.org/u-yednostisila-vpliv-reformi-detsentralizatsiyi-namistsevi-byudzheti-v-ukrayini/

Goodpaster, K. (2011). Corporate Conscience. In: L. Bouckaert, L. Zsolnai, Handbook of Spirituality and Business. Palgrave Macmillan, London. https://doi.org/10.1057/9780230321458_41
Halkiv, L., Karyy, O., Kulyniak, I., \& Ohinok, S. (2020). Innovative, Scientific and Technical Activities in Ukraine: Modern Trends and Forecasts. 2020 IEEE Third International Conference on Data Stream Mining \& Processing (DSMP). Lviv, Ukraine. https://doi.org/10.1109/DSMP47368.2020.9 204148.

Hohnen, P. (2007). Corporate Social Responsibility. An Implementation Guide for Business. International Institute for Sustainable Development. Canada.

ISO 26000:2010. (2021). Guidance on social responsibility. https://www.iso.org/standard/42546.html\#: $\sim:$ text=ISO\%2026000\%3A2010\%20is\%20inten ded,part\%20of\%20their\%20social\%20respons ibility

Kardava, T. (2018). Decentralization for Regional Infrastructure Development in Eastern Georgia. International Journal of Innovative Technologies in Economy, 1, 10-13. https://doi.org/10.31435/rsglobal_ijite/0106 2018/5652

Kendrick, S. K., Kendrick, M., \& Saakova, A. (2014). A Case Study in Corporate Social Responsibility. Journal of Eastern European and Central Asian Research, 1(1), 10. https://doi.org/10.15549/jeecar.v1i1.36

Lee, S. (2020). Corporate social responsibility and COVID-19: Research implications. Tourism Economics. https://doi.org/10.1177/1354816620978136

Malik, A., Sharma, P., Pereira, V., \& Temouri, Y. (2021). From regional innovation systems to global innovation hubs: Evidence of a Quadruple Helix from an emerging economy. Journal of Business Research, 128, 587-598. https://doi.org/10.1016/j.jbusres.2020.12.00 9

Menke, W. (2018). Factor Analysis. Geophysical Data Analysis (Fourth Edition). New York: Academic Press, 207-222.

Mertens, K.M. (2013). Milton Friedman and Social Responsibility An Ethical Defense of the Stockholder Theory. Oslo.

Ministry of Finance of Ukraine. (2021). Execution of Local Budget Revenues. 
https://mof.gov.ua/uk/vykonanniadokhodiv-mistsevykh-biudzhetiv.

Newman, C., Rand, J., Tarp, F., \& Trifkovic, N. (2020). Corporate Social Responsibility in a Competitive Business Environment. The Journal of Development Studies, 56(8), 1455-1472, https://doi.org/10.1080/00220388.2019.169 4144

Odintsov, O., Yevtukhova, T., Vasylkonova, E., \& Kunchenko-Kharchenko, V. (2020). Influence of tax burden on economic development of agricultural enterprises in Ukraine. Journal of Eastern European and Central Asian Research, 7(1), 150-162. https://doi.org/10.15549/jeecar.v7i1.328

On Accounting and Financial Reporting in Ukraine. (1999). Law of Ukraine on July 16, 1999 № 996-XIV. https://zakon.rada.gov.ua/laws/show/99614 ?lang=en\#Text

Osagie, E.R., Wesselink, R., Blok, V., \& Mulder, M. (2019). Contextualizing Individual Competencies for Managing the Corporate Social Responsibility Adaptation Process: The Apparent Influence of the Business Case Logic. Business \& Society, 58(2), 369-403. https://doi.org/10.1177/0007650316676270

Peake, W. O., Harris, M. L., McDowell, W. C., \& Davis, P. E. (2015). Get What You Give? An Examination of Enlightened Self-Interest, Philanthropic Intent, and Engagement in Philanthropy for Small Firm Owners. Journal of Small Business Strategy, 25(2), 79-96

Pochtovyuk, A., Semenikhina, V., Onyshchenko, O., \& Ruban, B. (2019). The formation and development of social responsibility of business: Ukrainian experience in a context of decentralization. SHS Web of Conferences, 61, 01018. https://doi.org/10.1051/shsconf/201961010 18

Questions for assessing of developing CSR business. (2021). https://docs.google.com/forms/d/1Gl0oXZd7 Qs2aG5Z5hcKkKiOv00BR879tQF117kV6iR0/ edit

Reznik, N.P, \& Slobodianyk, A.M. (2021). Social Responsibility of Ukrainian Business in the Conditions of the Covid-19 Pandemic:
Foreign and Domestic Practice. The Importance of New Technologies and Entrepreneurship in Business Development: In The Context of Economic Diversity in Developing Countries, 1, 194, 1850-1858. https://doi.org/10.1007/978-3-030-692216_133. PMCID: PMC7972443.

Scherer, A.G., \& Palazzo, G. (2011). The New Political Role of Business in a Globalized World: A Review of a New Perspective on CSR and its Implications for the Firm, Governance, and Democracy. Journal of Management Studies, 48, 899-931. https://doi.org/10.1111/j.14676486.2010.00950.x

State Statistics Service of Ukraine. (2021). Statistical Information. http://www.ukrstat.gov.ua/

Stock market infrastructure development agency of Ukraine, (2021). https://smida.gov.ua/db

Taherdoost, H. (2017). Determining Sample Size; How to Calculate Survey Sample Size. International Journal of Economics and Management Systems, 2, 237-239.

Thomson Reuters. (2013). Corporate Responsibility Ratings (TRCRR). https://www.thomsonreuters.com/content/ dam/openweb/documents/pdf/tr-comfinancial/methodology/corporateresponsibility-ratings.pdf

Walker Information. (2021). https://walkerinfo.com/

YouControl. (2021). https://youcontrol.com.ua/our_possibility/

Young S. (2013) Enlightened Self-interest. In S.O. Idowu, N. Capaldi, L. Zu, A.D. Gupta, Encyclopedia of Corporate Social Responsibility. Springer, Berlin, Heidelberg. https://doi.org/10.1007/978-3-642-280368_220 


\section{ABOUT THE AUTHORS}

Valeriia Baranova, email:

v.v.baranova@karazin.ua

Valeriia Baranova, Doctor of Economic Sciences, V.N. Karazin Kharkiv National University, Kharkiv, Ukraine.

Tetiana Kulinich, Ph.D. in Economics, Lviv Polytechnic National University, Lviv, Ukraine.

Olena Dutchak, PhD in History, Vasyl Stefanyk Precarpathian National University, IvanoFrankivsk, Ukraine.

Viktor Zvonar, Doctor of Economic Sciences, Borys Grinchenko Kyiv University, Kyiv, Ukraine.

Liudmyla Denyshchenko, postgraduate student, Volodymyr Dahl East Ukrainian National University, Severodonetsk, Ukraine. 